\title{
Common Backswimmer Notonecta glauca (Linnaeus 1758) (Hemiptera: Notonectidae) ${ }^{1}$
}

\author{
Taryn B. Griffith and Jennifer L. Gillett-Kaufman²
}

\section{Introduction}

Notonecta glauca, the common backswimmer (Figure 1), is an aquatic insect in the family Notonectidae. Insects in this family are commonly referred to as backswimmers or greater water boatman. Notonectids propel themselves through the water with their ventral side (belly) facing upwards, hence their common name of backswimmers (Figure 2). Notonectids can inflict wounds to humans with their proboscis (mouthpart), but this is very rare and often is a result of rough handling.

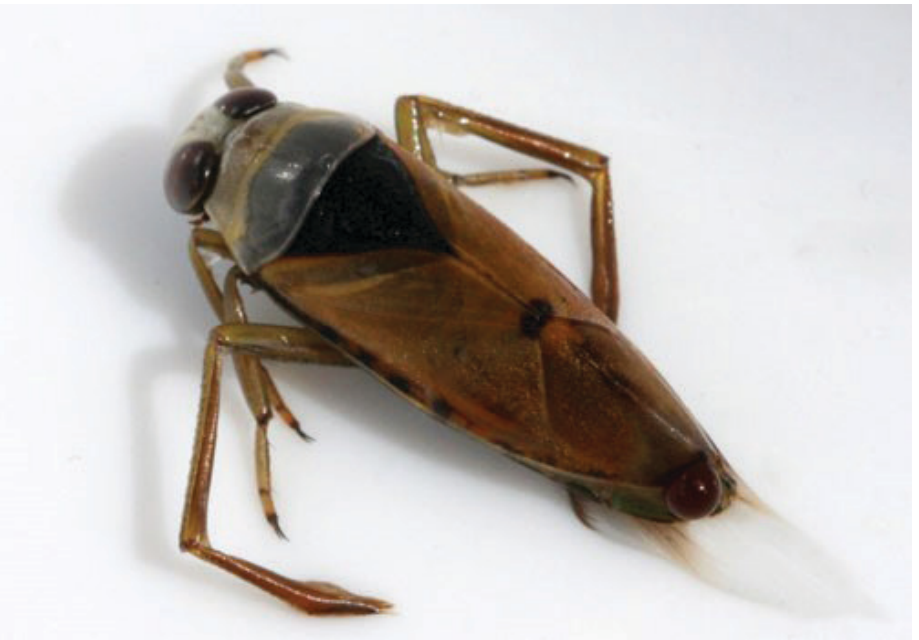

Figure 1. An adult Notonecta glauca (Linnaeus).

Credits: David Nicholls

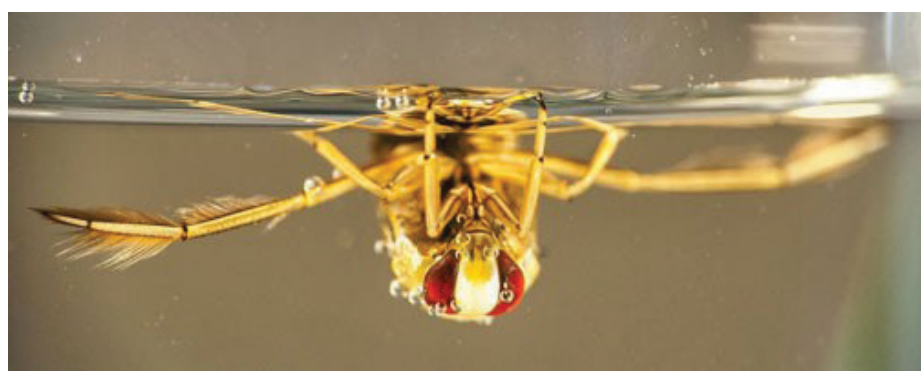

Figure 2. Notonecta sp. adult resting upside down underwater, which is typical of all Notonectids.

Credits: JRxpo. Flickr.com

\section{Distribution}

Although commonly collected in Europe (Soós et al. 2009), the common backswimmer can range from parts of northern Africa to western Siberia and northwestern China (Berchi 2013). Notonecta glauca is typically found in inland freshwater ponds, although they can be found in eutrophic (water excessively enriched in nutrients) freshwater bodies near the sea (Kjærstad et al. 2009). Many other Notonecta species occur in North America north of Mexico (Torre Bueno 1905). It is unclear if this species could become established if introduced to Florida, but its current distribution includes several locations with similar climates and habitats.

1. This document is EENY-738, one of a series of the Entomology and Nematology Department, UF/IFAS Extension. Original publication date August 2019. Visit the EDIS website at https://edis.ifas.ufl.edu for the currently supported version of this publication.

2. Taryn B. Griffith, Horticultural Sciences Department; and Jennifer L. Gillett-Kaufman, associate Extension scientist, Entomology and Nematology Department; UF/IFAS Extension, Gainesville, FL 32611.

The Institute of Food and Agricultural Sciences (IFAS) is an Equal Opportunity Institution authorized to provide research, educational information and other services

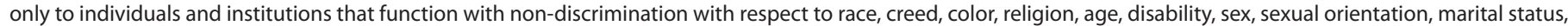

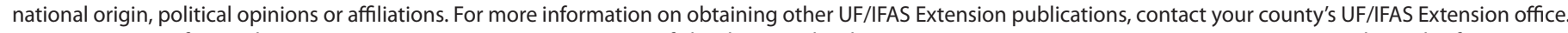
U.S. Department of Agriculture, UF/IFAS Extension Service, University of Florida, IFAS, Florida A \& M University Cooperative Extension Program, and Boards of County Commissioners Cooperating. Nick T. Place, dean for UF/IFAS Extension. 


\section{Description}

\section{Eggs}

Notonecta spp. have white oblong eggs. These eggs can be found attached to aquatic vegetation (Figure 3). Adult Notonecta from Great Britain lay eggs in the fall and or spring (this varies by species), and there is only one generation a year (Briers 1998).

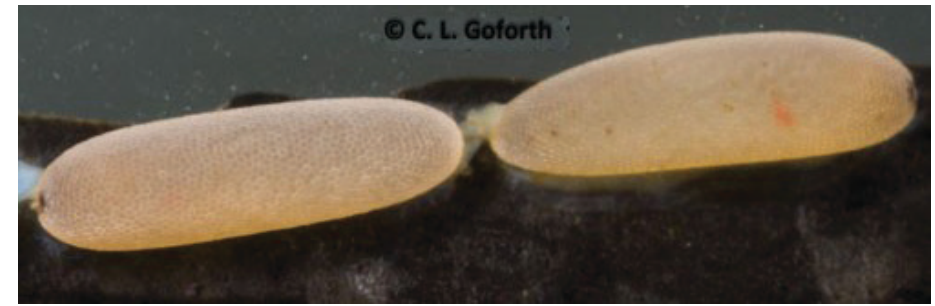

Figure 3. Notonecta sp. eggs on aquatic vegetation, which is typical of all Notonectids.

Credits: Chris Goforth, https://thedragonflywoman.com

\section{Nymphs}

Like many true bugs, nymphs of this species look like small adults. They do not have fully developed wings as nymphs, and they have much shorter abdomens. They are often more uniform in color and their pronotum is not darker than the rest of the body, as seen in the adults. British species of Notonecta have been reported to have five nymphal instars that develop over the summer months (Briers 1998).

\section{Adults}

The most easily identifiable feature of insects in the

Notonectidae family are their long hind legs that are used to propel themselves in the water. Adult Notonecta spp. have a pale tan head and legs. The pronotum (area just behind the top of the head) is darker than the head and the elytra (hardened forewings) can be a range of tan colors. The eyes are large and dark red in color. Fully-grown adults measure about $16 \mathrm{~mm}$ (Reynaldi et al. 2011).

Notonecta glauca adults and immatures breathe by taking in air rather than dissolved oxygen from the water; however, their body is covered in hair-like structures called setae and microtrichia that aid them in their aquatic lifestyle. A backswimmer's entire body except the pronotum (area behind the head), head, and legs is covered in these hairs. The hairs create a film that traps air, allowing the insect to absorb oxygen while underwater and keep their bodies dry (Kuru et al. 2011). The setae tend to be larger and sparser in comparison to the denser patches of microtrichia. Only microtrichia are present under the upper side of the elytra. Due to the thickness of the microtrichia, air can be held in the film for up to 130 days. This air film is visible with the naked eye and appears as a silvery sheen on the body (Kuru et al. 2011).

\section{Behavior}

The common backswimmer preys on a variety of other aquatic organisms, like Daphnia spp. (water fleas) (Giller and McNeill 1981). Notonecta spp. most commonly prey on other insect species, but have been observed to prey on fish eggs, fry, and tadpoles (González and Leal 2010). Notonecta glauca have been observed to prey on the larvae of the mosquito Culex pipens (Reynaldi et al. 2011). When hunting, the common backswimmer captures its prey by using its raptorial forelegs or middle legs. These legs have grasping surfaces making it difficult for prey to escape (Giller and McNeill 1981). They are ambush predators that wait for an opportunity to strike unsuspecting prey (Ellis and Borden 1970, Giller and McNeill 1981).

The common backswimmer prefers environments with lush vegetation in which to hide itself. When aquatic plants are present, the common backswimmer will reside on the edge of the plant, usually mid-way up the plant, a preference not influenced by prey selection (Giller and McNeill 1981). Residing on the edge of the plant allows the common backswimmer to more easily observe its surroundings and snatch passing prey (Figure 4) (Giller and McNeill 1981). Due to its preference for vegetation and its low affinity for the surface, the common backswimmer does best in a complex environment where avoiding the surface and having ample vegetation to hide in will protect it from predation.

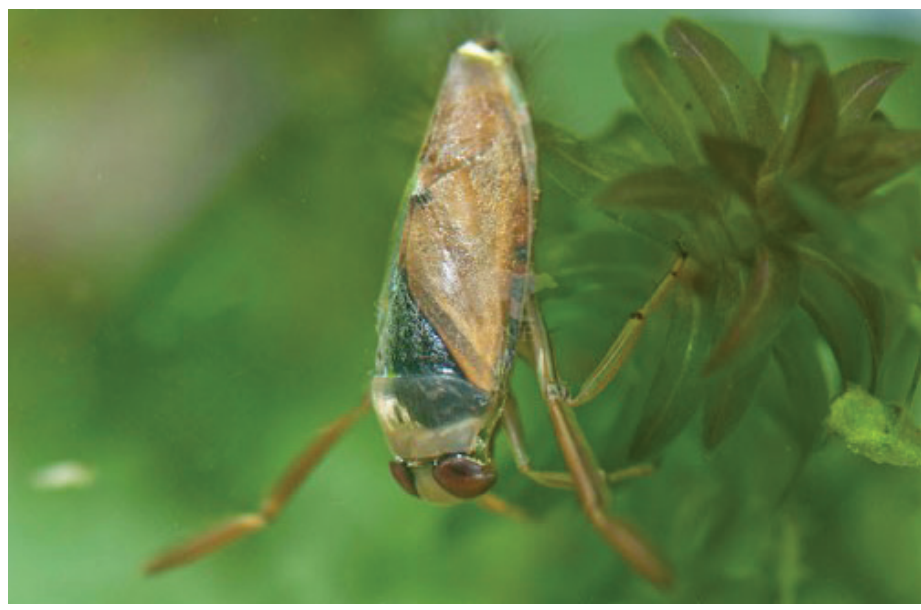

Figure 4. Notonecta glauca (Linnaeus) adult perched on aquatic vegetation.

Credits: @Dick Klees/Studio Wolverine.

The common backswimmer sucks the hemolymph from its prey (bodily fluid in invertebrates that is comparable to blood). Notonecta glauca extracts food slower and has less of a response to surface activity to than other Notonecta 
species (Cockrell 1984). One reason for a comparatively lower response to surface activity is that they reside at lower depths rather than the water surface (Cockrell 1984). At air temperatures below $15^{\circ} \mathrm{C}\left(59^{\circ} \mathrm{F}\right)$, Notonecta glauca spends the majority of the time underwater. Above $15^{\circ} \mathrm{C}\left(59^{\circ} \mathrm{F}\right)$ it will spend more time above water than below the surface. At $5^{\circ} \mathrm{C}\left(41^{\circ} \mathrm{F}\right)$, it tends to stay completely submerged (Cockrell 1984). In highly oxygenated water and at higher temperatures, the common backswimmer prefers to stay submerged (Cockrell 1984).

\section{Selected References}

Berchi G. 2013. "Checklist and distribution of the family Notonectidae in Romania, with the first record of Notonecta maculata Fabricius, 1794 (Hemiptera: Heteroptera: Nepomorpha)." Zootaxa 3682: 121-132.

Briers RA. 1998. Metapopulation ecology of Notonecta in small ponds. University of Sheffield Ph.D. Dissertation. Sheffield, England. p. 154

Cockrell BJ. 1984. "Effects of temperature and oxygenation on predator-prey overlap and prey choice of Notonecta glauca." Journal of Animal Ecology 53: 519-532.

Ellis RA, Borden J. 1970. "Predation by Notonecta undulata on larvae of the yellow fever mosquito." Annals of the Entomological Society of America 63: 963-973.

Giller PS, McNeill S. 1981. 'Predation strategies, resource partitioning and habitat selection in Notonecta (Hemiptera/ Heteroptera)." Journal of Animal Ecology 50: 789-808.

González A, Leal J. 2010. "Predation potential of some aquatic insects (Pantala, Coenagrion, Tropisternus, Notonecta and Sigara) on common carp fry." Journal of Applied Aquaculture 5: 77-82.

Kjærstad G, Dolmen D, Olsvik HA, Tilseth E. 2009. “The backswimmer Notonecta glauca L. (Hemiptera, Notonectidae) in central Norway." Norwegian Journal of Entomology 56: 44-49.

Kuru PD, Schneider ES, Melskotte JE, Brede M, Leder A, Barthlott W. 2011. "Super hydrophobic surfaces of the water bug Notonecta glauca: a model for friction reduction and air retention." Journal of Nanotechnology 2: 137-144.
Reynaldi S, Meiser M, Liess M. 2011. "Effects of the pyrethroid fenvalerate on the alarm response and on the vulnerability of the mosquito larva Culex pipiens molestusto to the predator Notonecta glauca." Aquatic Toxicology 104: $56-60$.

Soós N, Boda P, Csabai Z. 2009. "First confirmed occurrences of Notonecta maculata and N. meridionalis (Heteroptera: Notonectidae) in Hungary with notes, maps, and a key to the Notonecta species of Hungary." Folia Entomologica Hungarica 70: 67-78.

Torre Bueno JR. 1905. “The genus Notonecta in America north of Mexico." Journal of the New York Entomological Society 13: 143-167. 